\title{
CRITERIA AND THEIR INFLUENCE ON THE TACTICAL DECISION-MAKING OF COMMANDERS IN OPERATIONS
}

\author{
Jiří ČERNÝ \\ University of Defence, Brno, Czech Republic \\ jiri.cerny@unob.cz \\ Jaromír PITAŠ \\ University of Defence, Brno, Czech Republic \\ jaromir.pitas@unob.cz
}

\begin{abstract}
Decision-making is one of the core activities of commanders in operations. Commanders (with the help of staffs) carry out decision making, or the decision-making process in planning, because decision-making processes lie at the heart of planning processes. Commanders' and staffs' decision-making consists of the creation and assessment of various alternatives (variants of actions) according to certain aspects (criteria) and their mutual comparison, risk assessment, selection of the most advantageous (optimal) alternative and the adoption of a decision. In this paper, the authors focus on the method of deriving (selecting) a set of criteria from the objectives of the operation and their formulation for subsequent use in the creation, analysis, comparison and selection of a variant of action. The reason the authors carefully examine the significance of the influence of criteria on commanders' decisions is primarily the fact that these actions are not elaborated in detail in Alliance documents, which may subsequently affect the choice of optimal variants (decisions) regarding the actions of their own troops in joint (NATO) operations.
\end{abstract}

KEYWORDS: commander, decision-making, method of deriving of criteria, courses of action

\section{Introduction}

The decision-making process has a dominant role in planning the operation (combat). The core of the entire decisionmaking process is the logical procedure of the commander and his/her staff, based on the processing of information when preparing the decision. In practice, it involves a sequence of successively performed actions with more than one alternative solution (choosing between two or more mutually exclusive solution variants), while the subsequent implementation of one of them (selected by the commander) is expected to achieve the objective (objectives) of the operation (NATO, 2016; Beatty, 2019).

The planning and decision-making process in the military environment (for ground forces) involves interrelated actions of the commander (and his/her staff) leading to an understanding of the objective, preparation of an operation plan (OPLAN) and preparation of an operation order (OPORD). During the process, commander, chief of staff, and specific 
planners, after understanding the objective, anticipate the upcoming situation in the operating environment, analyze its individual factors, and assess threats and risks. Based on the conclusions of the assessment, they propose an effective method of achieving the required condition (objective) by transferring the results of analyzes and the commander's intention into specific actual courses of combat action (COA) (Beatty, 2019; Správa doktrín, 2007).

The decision-making itself includes the creation of COA (solutions) according to certain aspects (criteria) and their analysis, mutual comparison, assessment (according to set criteria) and selection of the optimal (most advantageous) variant associated with the decision-making (Grasseová et al., 2013). Computer systems that contribute to the effectiveness of decision-making (Decision Support System), formalize and algorithmize the subsequent decisionmaking process. Then the process is implemented in a computer environment with the processing of the objective and undistorted data, which are related to the problem. The DSS system will use the corresponding model of tactical activity applied over the data on the current state and situation on the battlefield and based on these model variants of activities are subsequently created (Stodola, 2018).

The actual selection of a COA can be considered as the behavior of the bodies of a given level of command and control, the input to which is information - prepared in a certain way (clarified and analyzed) - and the output is a decision expressing a clearly formulated conclusion on the selection of one of the possible solutions as the basis for action of the controlled military forces. The criteria play an essential role in the creation, assessment and comparison of the individual variants of our troops' actions (i.e. when modeling future combat) (Černý, 2012; 2019).

The subject of this research task is the decision-making criteria in the planning and decision-making process.
The following verified or falsified hypotheses are the aim of the paper:

a) "Commanders set decision-making criteria for creating acceptable options in the planning and deciding process".

b) "Setting criteria and assessing their impact on the creation and selection of an activity variant belongs to a form of modelling".

To verify/falsify the hypotheses, a content analysis of the literature, a qualitative questionnaire survey, and a static analysis of the results of the questionnaire survey have been used.

\section{Analysis of the Problem}

The key moment for creating a framework for the creation, analysis and comparison of COAs is the creation and formulation of individual criteria.

Preparation and creation of criteria already begins with the commander in the process of receiving and understanding the objective. With the staff, this activity takes place during the clarification of the objective and creation of the COA. The purpose of clarifying the objective is primarily to determine what needs to be done to fulfill the intention of the superior commander. The key is to analyze individual factors of the operating environment in order to create a framework for the creation of possible solutions and at the same time for their subsequent evaluation. With regard to the issues (criteria) addressed, the authors view as essential an analysis of the intentions of superiors, the objective itself, limitations, specific tasks, specified actions and their impact on the fulfillment of the objective. This analysis should be performed primarily in order to clearly define the requirements (limits) and conditions (restrictions) that any acceptable solution of the objective must meet, or to create essential criteria. (The term "essential criteria" has not yet appeared in the military sphere). 
Subsequently, considering the conclusions from understanding the objective and with regard to the assessment of the operating environment, the commander and his/her staff develops evaluation criteria to measure the relative effectiveness and efficiency of each variant against other created COAs of the action itself. For these criteria, it is essential that each criterion is assigned its weight by the commander (chief of staff). The commander tells these evaluation criteria to the individual planners responsible for the creation of COAs of the action, and at the same time modifies them in the course of the analysis of the variant. If time is of the essence, the staff assesses individual COAs using so-called screening criteria or verification criteria. In certain situations, these can basically replace both essential and evaluation criteria.

\subsection{Analysis of the Documents}

\subsubsection{Analysis of the Literature on} the Problem in General

The authors of the paper analyzed the following literature on this issue: Efficient Decision-Making: Analysis - DecisionMaking - Implementation and Assessment (Grasseová et al. 2013); Guidebook to Decision-Making Methods (Baker et al. 2001); Management methods in the public sector: theory, practice and methodology of application (Ochrana 2007); Management decision-making: Procedures, methods and tools (Fotr et al., 2010). The authors then used the comparative method of the individual conclusions of the analysis of available resources to compare the managerial and military approaches. The paper by Grasseová et al. (2013) deals in Chapter 4 with the issue of creating objectives for decisions, essential and evaluation criteria. In the introduction, she leans towards Baker et al. (2001), Ochrana (2007), and Fotr et al. (2010). The content of the analyzed literature of the above authors shows that issues related to the determination of decision-making goals (solving a problem) and the subsequent definition of evaluation criteria are rigorously distinguished. Fotr et al. (2010) state that the criteria for evaluating the COA of a solution are usually derived from the set goals of the solution. This indicates a close relationship between the goal of the solution and the assessment criterion. Fotr et al. (2010), on pages 26 and 27, address the evaluation criteria that represent aspects chosen by the decision-maker (based on their organizational value list), which are used to assess the benefits of individual COAs of decisions in terms of achieving (or the degree to which they are achieved) the partial objectives of the solved decision problem. Grasseová et al. (2013) divide criteria into essential and evaluative. They define essential criteria as requirements and conditions that must be met by any acceptable solution of the problem.

\subsubsection{Analysis of Professional Military}

\section{Literature}

The authors then performed a content analysis of the available military literature produced by the Alliance, the Czech Republic and the US that focuses on the issues addressed. Among the main sources, the authors discussed in particular:

a) US Army Field Manual FM 6-0 (Headquarters, 2014);

b) Alliance Procedural Publication APP-28 (NATO, 2018);

c) Alliance doctrine ATP-3.2.2

(NATO, 2016);

d) Pub-53-01-2 (Správa doktrín, 2007);

e) Selected Standing Operational Procedures from Brigades and Combat Battalions (Beatty, 2019; Černý, 2019);

f) Information support of the commander's decision-making process (Stodola, 2018; Černý \& Hrůza 2010; Pitaš \& Crhák 2016; Blaha \& Brabcová 2012).

The Alliance Procedural Publication (APP), which describes the ground force 
planning process at the tactical level, describes evaluation criteria as "standards" that the commander and staff use to measure the relative effectiveness and efficiency of each COA against the others. At the same time, APP states that choosing the right criteria in the analysis of COAs helps to reduce bias before analyzing and comparing variants (NATO, 2018). However, neither the above procedural publication nor the subsequent US Army Field Manual provides a procedure (instruction) on how commanders should create evaluation criteria (it only states that "commanders adjust the selection of criteria and their weighting according to his/her experience and intent") (Headquarters, 2014). In connection with the above, they performed a subsequent analysis of the Military Decision-Making Process (MDMP) and the results confirmed the fact that commanders (and groups processing individual COAs) use the so-called evaluation criteria (called either 'evaluation criteria' or 'screening criteria'). These are announced either during the briefing at the end of the second step of MDMP, i.e. at the end of objective clarification, or immediately after the COA creation process has been completed. (Beatty, 2019; Černý, 2019)

In Headquarters (2014), the US Army Field Manual views the criterion as a standard - a rule or test to assess the solution by a measure of value. The problem solvers then create criteria to help with formulating and assessing possible solutions to the problem. The manual emphasizes the substantiation of the criteria by facts or assumptions. The problem solvers create two types of criteria: screening and evaluation.

Professor Stodola (2018) states that modelling of tactical tasks is usually only one part vital to the creation of optimal variants of activity in the task performance. The models set out the criteria defining optimality, including the role that data and information on the environment and the situation of combat operations on the battlefield play in the models, and determine the relationships between processes. The task is to find the optimal solution according to the criteria and rules specified in the models.

\subsection{Questionnaire Survey}

To ascertain findings about the current state of knowledge and the application of decision criteria in the planning and decisionmaking process of the commander and his/her staff of the mechanized units of the Czech Army (AFCR), research was conducted using a questionnaire survey. Respondents were presented with 15 closed questions. To select the respondents, the method of targeted, quota sampling was used, the criterion of which was experience with the planning and decision-making process by the commander and his staff. Such experience means managing the planning and decisionmaking process from the position of commander or staff member involved in the planning process. The resulting qualitative data were then converted into quantitative form during the assessment. The answer "yes" was assigned a value of 1, "no" 2 and "I don't know" 3.

All respondents are members of the mechanized brigade of AFCR and are active professional soldiers, of which $3 \%$ were women and $97 \%$ men. $97 \%$ of respondents had taken part in several command and staff exercises in the last two years, where they had implemented the planning and decisionmaking process $(3 \%$ had completed one command and staff exercise).

Given the above it can be assumed that the practical experience of respondents in the monitored area is sufficient. Additionally, $88 \%$ of respondents had been in the service in the range of 6 to 20 years. The respondents had completed mainly college education (67\%) and $33 \%$ had high school or higher vocational education. The educational level also corresponded to the ranks, where $33 \%$ 
were in the rank of sergeant and sergeant major, $46 \%$ lieutenant and first lieutenant, and $21 \%$ captain and major.

For the purpose of this research, fifteen survey questions were selected:

1) Do you agree with the statement that the planning and decision-making process in operations involves the interrelated activities of the commander, staff and subordinate commanders?

2) Do you agree that planning an operation is the ability to understand the objective and the situation, anticipate the upcoming development and design an effective way (variant of action) to achieve the desired condition?

3) Do you agree with the statement that the Operation Plan (Combat Plan) is created on the basis of the commander's decision about a selected variant of his/her own actions?

4) Do you agree with the statement that the commander's decision-making is preceded by the creation, analysis and comparison of possible ways (variants) of his/her own actions?

5) Do you agree with the opinion that the preparation (creation) of COAs is carried out only after the analysis of the objective?

6) Is the creation of criteria part of the task analysis and assessment of operating environment factors?

7) Do you agree with the statement that the criteria are set by the commander?

8) Do you agree with the statement that criteria are "standards" that are used to measure the relative effectiveness and efficiency of each created variant against other variants of one's own actions?

9) Do you think that the chief of staff determines a weight for each proposed criterion based on an assessment of its relative importance in accordance with the commander's instructions?
10) As a commander (staff member), have I used or participated in the use of criteria for assessing individual COAs (evaluation criteria) during the planning and decision-making process?

11) Do you agree with the statement that, in addition to the evaluation criteria, planners assess each variant of their own actions by the screening criteria?

12) Do you agree with the statement that the staff uses the evaluation criteria to determine the advantages and disadvantages of each variant by comparing the strengths and weaknesses based on the criteria set by the commander and the expected variant of the enemy's actions?

13) Do you believe the statement to be true that the aim of the comparison of variants is an objective independent assessment of one's own variants of actions in comparison with the presumed variants of the opponent's actions using the criteria set by the commander?

14) Do you agree with the statement that the results of the comparison of individual COAs according to the criteria set by the commander are assessed in a decision matrix, or in a comparison table?

15) Are you convinced by the statement that after completing the analysis and comparison of options, the staff identifies its preferred option and prepares a recommendation to the commander to adopt one of the options to develop the Operation Plan (Combat Plan)?

\section{Research Result}

The results of the questionnaire survey are summarized in chart and comments on the answers to the questions asked. 


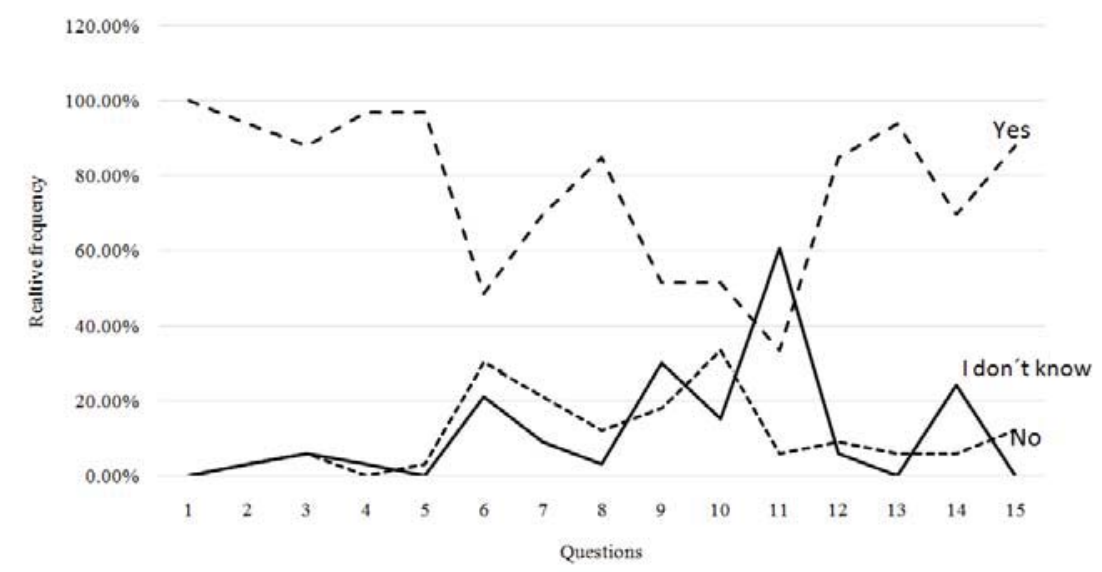

Figure no. 1: Relative frequency of answers to questions

The relative frequency expressed in Figure no. 1 confirms that respondents agree with the statements of questions $1-5$, as well as with those of questions 8 , 12, 13 and 15. The answers show that respondents understand the content and significance of the planning and decisionmaking process. What is important is the relative frequency of answers to questions 8,12 and 13 concerning the decision criteria that confirm knowledge of:

- the term criterion, like "standards", that is used to measure the relative effectiveness and efficiency of each created COA against other created COAs of one's own actions;

- the term "evaluation criterion" and its importance in the planning and decisionmaking process, because it determines the advantages and disadvantages of each variant by comparing strengths and weaknesses based on the criteria set by the commander and the expected COA of the opponent;

- the aim of applying the criteria that are used when comparing COAs is an objective, independent evaluation of one's own variants of actions in comparison with the presumed COAs of the opponent.

Figure no. 1 also shows two problematic questions (answer "No"), where at least $30 \%$ of the respondents answered "no". These are questions 6 and 10. Although some respondents stated that they understood the term criterion, the objectives of its application, including the content of the planning and decisionmaking process, they stated that the creation of criteria was not part of the analysis of tasks and the evaluation of operating environment factors.

The problem likely lies in the statement that, as a commander or staff member, the respondent was not involved in the application of criteria for the assessment of individual COAs.

The answer "I don't know" to the questions shown in Figure no. 1 points to the fact that, in the opinion of $30 \%$ of respondents, they were unaware that the chief of staff sets a weight for each proposed criterion based on an assessment of its relative importance in accordance with the commander's instructions. The answer "I don't know" highlighted another problem, where $60 \%$ of respondents did not know that in addition to the evaluation criteria, planners assess each COA according to the screening criteria. The answer to this question points to ignorance of the screening criteria and their application in the planning and decisionmaking process. 
Table no. 1

Arithmetic mean and median of answers to questions

\begin{tabular}{c|c|c|c|c|c|c|c|c}
\hline $\begin{array}{c}\text { Question } \\
\text { number }\end{array}$ & $\begin{array}{c}\text { Arithmetical } \\
\text { average }\end{array}$ & Median & $\begin{array}{c}\text { Question } \\
\text { number }\end{array}$ & $\begin{array}{c}\text { Arithmetical } \\
\text { average }\end{array}$ & $\begin{array}{c}\text { Muestion } \\
\text { number }\end{array}$ & $\begin{array}{c}\text { Arithmetic } \\
\text { al average }\end{array}$ & Median \\
\hline 1. & 1.00 & 1 & 6. & 1.73 & 2 & 11. & 2.27 & 3 \\
2. & 1.09 & 1 & 7. & 1.39 & 1 & 12. & 1.21 & 1 \\
3. & 1.18 & 1 & 8. & 1.18 & 1 & 13. & 1.06 & 1 \\
4. & 1.06 & 1 & 9. & 1.79 & 1 & 14. & 1.55 & 1 \\
5. & 1.03 & 1 & 10. & 1.64 & 1 & 15. & 1.12 & 1 \\
\hline
\end{tabular}

The arithmetic mean and median of all answers shown in Table no. 1 indicates a conflict (problem) in answers no. 6, 9, 10, 11 and 14. The median in Table no. 1 at question 6 and its arithmetic mean show, compared to the positive answers to the previous questions, that $50 \%$ of respondents "disagree" or "do not know" that the creation of criteria is part of the task analysis and the evaluation of operating environment factors.

The answer to question 9 appears to be similar; it points to a problem in the assertion that the chief of staff sets a weight for each proposed criterion, based on the assessment of its relative importance in accordance with the commander's instructions. With this question, more than $50 \%$ of respondents stated that they "disagree" or "do not know" about setting the weights of the criteria by the chief of staff.

The finding (question no. 10) that less than $50 \%$ of respondents stated that as a commander (staff member) he/she "did not use" or "do not know" about the use of, or "did not participate" in or "do not know" about the use of criteria for assessing individual COAs during the planning and decision-making process can be considered significant. Here we see a significant discrepancy between the positive statement on the knowledge of the process and the decision-making criteria as such, and their non-use in the planning and decisionmaking process.

More than $90 \%$ of respondents "do not agree" with, or stated "do not know" to the statement that, in addition to the evaluation criteria, planners assess each COA by the screening criteria. The median (3 - "don't know") of this question speaks of the ignorance of this term and the importance of its use within the process.

The last question that requires scrutiny is question 14 , where over $30 \%$ of respondents do not agree with the statement that the results of the comparison of individual COAs by the criteria set by the commander are evaluated in a decision matrix or correlation table, or do not know about the correlation table or use of such matrix. Here we have, however, a discrepancy with the answer to question no. 6. Hence, there are commanders and staff members (50\%) who, on the one hand, state that the creation of criteria " $i s$ " or "is not" part of the objective analysis and evaluation of operating environment factors. On the other hand, approximately $70 \%$ use a decision matrix with criteria set by the commander.

The number of respondents did not make it possible to perform a relevant test to determine whether a negative or "do not know" answer depended on the level of education, length of practice or rank.

\section{Discussion}

The first hypothesis, that commanders set decision criteria for the creation of acceptable COAs in the planning and decision-making process, was falsified based on the results of the questionnaire survey.

The reason for the falsification is the finding that setting decision criteria (essential criteria, evaluation criteria and screening 
criteria) is not a standard part of the planning and decision-making process. According to the authors, the reasons are mainly:

- ignorance regarding the creation of essential and screening criteria;

- ignorance regarding who, in addition to the commander, sets the criteria in the planning and decision-making process, and who weights (establishes the validity) for the individual criteria;

- the determination of criteria and weights not being incorporated in the SOPs.

Failure to incorporate the setting and application of criteria (essential, evaluation and screening) into SOPs means that the setting of evaluation criteria depends entirely on the experience and discretion of the commander (building on the objective clarification and conclusions of the analysis of operating environment factors).

The second hypothesis, that $\mathrm{COA}$ selection in the planning and decision-making process is carried out on the basis of the set decision-making variants, was also falsified. The reason lies in the failure to incorporate the application of decision-making variants (variant selection) in the SOPs. The result is a situation where only evaluation criteria are used, but this is limited by the experience of the commander (chief planner) and the discretion of individual commanders and their staff planners.

The analysis revealed two problems as to why the hypotheses were falsified:

- ignorance of the essential and screening criteria;

- failure to incorporate the issue of setting criteria, weighting and their application in creating and selecting variants.

The identified problems can be solved by implementing the following steps:

a) based on the analysis of the literature, to design and incorporate a scenario for setting criteria, their weighting and application in the creation and selection of variants into the SOPs of the commanders and staffs of mechanized battalions and brigades; b) train commanders and staff to understand changes in SOPs;

c) verify and assess the functionality of updated SOPs;

d) keeping SOPs up-to-date.

\section{Conclusion}

The use of advanced methods of management decision-making at the tactical level in the military decision-making process is possible and can significantly eliminate subjective factors. However, their use is limited by numerous conditions to be met.

The first condition and also a limiting factor is the time available. There will never be enough time to prepare these comparatively complex tools when conducting combat. They can be only used if the time permits. The available time factor can be partially compensated by preparation, either in the form of software applications in which the necessary data is entered, or by prepared planners of a specific element of the command.

The second condition is that users of these tools must understand them and be familiar with their strengths and weaknesses. This can only be achieved through constant theoretical and practical training at the corresponding qualitative level. This training should take place at the technical level (ability to handle tools, which requires some mathematical knowledge, and knowledge of the tools specifically used) and at the content level. Senior officers involved in decision-making and the preparation of documents for decision-making should understand planning processes and also understand such concepts as well- and badly-structured decision-making problems, decisionmaking under uncertainty, the influence and function of utility on decision-making, attitude to risk, etc. Advanced decisionmaking methods cannot be used unless the pitfalls of decision-making processes are appreciated. 
The third condition is ensuring the competence of commanders and staffs to make decisions. Commanders and staff will be competent only with sufficient education and experience. Based on the acquired theoretical knowledge and experience with these processes, they must be able to apply information in accordance with the applicable doctrinal principles, and be able to adapt everything to the specific conditions of the operating environment. Such competence cannot be acquired by mere study or practice. It is necessary to combine both education, experience, and practice. In other words, in order to meet this condition, it is necessary to regularly practice staff decision-making processes with various scenarios, or with historical studies of older and more recent wars.

The set hypotheses were falsified and the analysis of the research results indicated the reasons for not determining or applying decision criteria in the planning and decision-making process of the commander and staff. Knowledge of the causes and problems associated with not determining or applying decision criteria, combined with an analysis of the literature, allowed possible scenarios for the creation and use of criteria to be proposed.

The subsequent research task will focus on testing scenarios in the planning and decision-making process of the commander and staff, with the subsequent selection of the scenario and its incorporation into the brigade SOP.

This paper has been created as part of the research project Methods of Strategic Analysis Usable at the Ministry of Defense of the Czech Republic.

\section{REFERENCES}

Baker, D. et al. (2001). Guidebook to Decision-Making Methods. WSRC-IM-200200002 U.S. DoE.

Beatty, S. (2019). MDMP: The Military Decision Making Process. Madison: Mentor Enterprises. Inc.

Blaha, M., \& Brabcová, K. (2012). Decision-making by effective C2I system. Proceedings of $7^{\text {th }}$ International Conference on Information Warfare and Security (ICIW), 44-50.

Černý, J. (2012). Modular structure of command and control for operations generation. Ekonomika a management, Vol. 2, 114-122.

Černý, J. (2019). Vojenský plánovací a rozhodovací proces v operacích. Praha: Powerprint.

Černý, J., \& Hrůza, P. (2010). Informative Management and its Influence over Organization of Command and Control in Military Operations. Pre-Conference Proceedings of the Special Focus Symposium on $2^{\text {nd }}$ IKS: Information and Knowledge Systems, 19-26.

Department of the Army. (2014). Commander and Staff Organization and Operations. FM 6-0. Washington, USA: Headquarters, Department of the Army.

Fotr, J. et al. (2010). Manažerské rozhodování: Postupy, metody a nástroje. 2. vydání. Praha: Ekopress.

Grasseová, M et al. (2013). Efektivní rozhodování: Analyzování - Rozhodování Implementace a hodnocení. Brno: Edika.

Kepner, Ch.H., \& Tregoe, B.B. (2006). The New Rational Manager. Princeton: Pricenton Resarech Press.

NATO Standardization Office. (2016). Command and Control of Allied Land Forces. ATP-3.2.2. Edition B, Version 1. Brussel: NATO Standardization Office (NSO). 
NATO Standardization Office. (2018). Tactical Planning for Land Forces. APP- 8. Edition A, Version 1. Brussel: NATO Standardization Office (NSO).

Ochrana, E. (2007). Manažerské metody ve veřejném sektoru: teorie, praxe a metodika uplatnění. Praha: Ekopress.

Pitaš, J., \& Crhák, M. (2016). Ř́zení rizik jako podpora rozhodovacího procesu $\mathrm{v}$ resortu Ministerstva obrany.Vojenské rozhledy (Czech Military Review), Vol. 25, Issue 57(1), 114-124.

Správa doktrín Ředitelství výcviku a doktrín. (2007). Štábní práce v operacích. Pub-5301-2. Část I. Vojenská publikace. Vyškov: Správa doktrín Ředitelství výcviku a doktrín.

Stodola, P. (2018). Informační podpora rozhodovacího procesu velitele. Praha: Powerprint. 